\title{
The Popes of Rome in Post-Byzantine Wall Paintings from Romania
}

\author{
Vlad Bedros*
}

\begin{abstract}
This study aims to bring forth two iconographic contexts which relate to the issue of the primacy of Rome. The first one dwells upon the evidence taken from Byzantium and the Balkans, while the second follows this line of investigation into the Romanian Post-Byzantine heritage. The cult of Saint Peter was strong enough in Byzantium as to prevent any refutation of his primacy, even during the harshest quarrels with Rome. This could explain the presence of Roman Popes (most frequently of St. Sylvester) in the procession of saintly bishops depicted in Moldavian apses at the end of the $15^{\text {th }} \mathrm{c}$. and in the $16^{\text {th }} c$., but equally in Wallachian iconographic programs from the $16^{\text {th }}$ and $17^{\text {th }}$ c. This phenomenon might hint at a claim to the plenitude of the apostolic tradition for the local Church, but also at a polemical anti-Latin discourse, which makes use of papal iconic portraits in contexts with strong ecclesiastic imprint.
\end{abstract}

Keywords: Rădăuți Middle Byzantine iconography, Late Byzantine iconography, Post-Byzantine iconography, Popes of Rome, apsidal programs, polemical imagery

This study ${ }^{1}$ aims to bring forth two iconographic contexts which relate to the issue of the primacy of Rome. The first one dwells upon evidence taken from Byzantium and the Balkans, while the second follows this line of investigation into the Romanian Post-Byzantine heritage. I shall aim at arguing that the primacy of Peter among the Apostles and of his heirs on the See of Rome within the Christian oikumene were ideas never abandoned by Eastern Christianity, receiving a visual expression in the selection of saintly bishops depicted in the apse and elsewhere within the iconographic programs of the Late and Post-Byzantine pictorial traditions of both Moldavia and Wallachia.

The first argument is prompted by the peculiar redaction of the Communion of the Apostles, in the apse of the basilica of Holy Wisdom in Ohrid (c. 1050), in which Peter is depicted in an emphasized proskynesis

\footnotetext{
* Associate Professor PhD., National University of Arts, Bucharest, "G. Oprescu” Institute of Art History, v.bedros@unarte.org

${ }^{1}$ This work was supported by a grant of the Romanian Ministry of Research and Innovation, CCCDI-UEFISCDI, project number PN-III-P1-1.2-PCCDI-2017-0326/49 PCCDI, within PNCDI III.
} 
which puts him in sharp contrast with the other stately participants; he bends much lower than Saint Paul, who opens the opposite procession of Apostles. Commenting on this idiosyncrasy, Branislav Cvetković argued that such a firm separation of Peter from the other disciples, reinforced by the detail of his bare outstretching hands, represents a watchful choice made by the donor of the frescoes ${ }^{2}$. Being an adamant polemist against the Latins, the archbishop Leo would have intentionally abandoned all deference towards the founder of the Roman church, and such a mind-set was echoed by the depiction of Peter in a posture of inclinatio plena; moreover, Christ gives his benediction to the group of Apostles led by Paul. Cvetković considered that the Communion of Apostles ordered by Leo, with its subtle asymmetries, was conceived as a visual rebuke aimed at those who declared themselves vicarii Petri and, by the same token, at those under their spiritual authority ${ }^{3}$.

Such assertion proves difficult to embrace, for two reasons. First, the cult of Saint Peter preserved its intensity in Byzantium, even throughout the most fervent polemics with the Latins. As Vera von Falkenhausen has proved, an alleged scorning of Peter as founder of the archbishopric of Rome was one of the pretexts invoked by the leaders of the Fourth Crusade in their effort of legitimizing the holy war against the Greeks, but there is a total lack of other documents which would substantiate such accuse ${ }^{4}$. On the contrary, there were several churches dedicated to Saint Peter within the New Rome, and chapels under his patronage existed in the Imperial Palace and in Hagia Sophia ${ }^{5}$. Should one mention a specific feature of the Byzantine cult of the prince of the Apostles, one would point at his permanent association with Saint Paul; this goes as far as to generate in the hagiographic material dedicated to other homonymous saints the existence of parallels established with homologue saints named Paul. The single controversial aspect related to Peter is the fact that he was married (the Gospel clearly speaks of his mother in law), but, surprisingly, this argument was never brought forth by the Byzantines during the dispute concerning the celibacy of the secular clergy ${ }^{6}$. The cult of Peter in Byzantium is validated not only by literary evidence; his chains were venerated in Constantinople as early as the $9^{\text {th }}$ century, when his miraculous escape from prison received a day of commemoration (on the $16^{\text {th }}$

\footnotetext{
${ }^{2}$ Branislav Cvetković, "Intentional asymmetry in Byzantine imagery: The Communion of the Apostles in St. Sophia of Ohrid and later instances", in Byzantion, t. 76 (2006), pp. 74-96 (esp. 75-84).

${ }^{3}$ Ibidem, pp. 80-84.

${ }^{4}$ Vera von Falkenhausen, "San Pietro nella religiosità bizantina", in Bisanzio, Roma e l'Italia nel'Alto Medioevo: Settimane di studio del Centro Italiano di Studi sull'Alto Medioevo 34, 3-9 aprile 1986, II, Presso la sede del Centro, Spoleto, 1988, pp. 627-674.

${ }^{5}$ Raymond Janin, La géographie ecclésiastique de l'Empire Byzantin, Première partie: Le siège de Constantinople et le Patriarcat Ecuménique, III, Les églises et les monastères, $2^{\text {nd }}$ ed., Institut français d'études byzantines, Paris, 1969, pp. 397-402.

${ }^{6}$ Vera von Falkenhausen, “San Pietro nella religiosità bizantina”, pp. 628-638.
} 
of February), while at the same time a canon for the holy chains was composed by Joseph the Hymnographer. Another relic associated with Peter, venerated in his chapel from the Imperial palace, was the knife he used for cutting off Malchus's earlobe ${ }^{7}$. The cult of Peter was intense enough as to prompt many Byzantine pilgrims to visit Rome; but the target of their devotion was not only the tomb of Peter, but also the tomb of Paul, and the two Apostles were so closely connected in the Byzantine devotion that, in several pilgrim books, their tombs were described as located on the same premises $^{8}$. The cult of Saint Peter was however strong enough in Byzantium as to prevent any refutation of his primacy; even during the harshest quarrels with Rome, the Byzantines merely argued that the primacy of Rome was given not by Peter as a founder of the Holy See, but by its status of imperial capital city (a status lost once the New Rome was elected by Constantine) ${ }^{9}$.

Coming back to the church in Ohrid, another aspect that questions an alleged intention of disdaining the Papacy is represented by the selection of bishops represented in its southern pastophorion: six popes of Rome, namely Vigilius, Clemens, Leo, Gregory and Sylvester ${ }^{10}$. It is true that the apse is reserved for the saintly bishops of the New Rome, but seeing this as a sign of inferiority assigned to the See of Rome would be inaccurate, as the eastern chapels are not spaces of secondary relevance, being assimilated to the sanctuary and constantly interpreted by the mystagogical texts in close relationship with the apse ${ }^{11}$.

This aspect opens the second line of inquiry, which I shall follow into the Romanian Post-Byzantine heritage. First, I would like to stress upon the presence of Roman Popes in the procession of saintly bishops depicted in Moldavian apses at the end of the $15^{\text {th }}$ century and in the $16^{\text {th }}$ century ${ }^{12}$. Among them, the most popular seems to be St. Sylvester, who is represented alongside the Three Hierarchs (John Chrysostom, Basil the Great and Gregory the Theologian) in the central section of the procession at Pătrăuţi (Fig. 1) and Popăuţi (Fig. 2). Sylvester appears again at Dobrovăţ, but in a different context, as he is followed by two other Roman popes, Gregory the Great and Martin (Fig. 3); they occupy the third, fourth and fifth positions to the south, while opposite to them, on the fifth and sixth positions, are

\footnotetext{
${ }^{7}$ Ibidem, pp. 638-641.

${ }^{8}$ Ibidem, pp. 641-646.

${ }^{9}$ Ibidem, pp. 651-658.

${ }^{10}$ See, more recently, Branislav Todić, "Représentations de Papes Romains dans l'église Sainte-Sophie d'Ohrid. Contribution à l'idéologie de l'archevêché d'Ohrid", in Deltion tēs Christianikēs Archaiologikēs Hetaireias, ser. 4, t. 29 (2008), pp. 105-118, with a survey of the academic literature on this topic.

${ }^{11}$ B. Todić, "Représentations de Papes Romains", pp. 116-117.

${ }^{12}$ I commented upon these peculiar iconographic choices in a previous study, "Selecția sfinților ierarhi în absidele moldovenești (secolele XV-XVI)", in POLYCHRONION. Profesorului Nicolae-Șerban Tanașoca la 70 de ani, Publishing House of the Romanian Academy, Bucharest, 2012, pp. 65-75.
} 
depicted archbishops of Constantinople, Metrophanes and Nicephorus. One should be mindful that, in the same monument, the narthex depicts allegorically the main spiritual centres of the Eastern monasticism through their spiritual fathers (Saint Sabbas for Jerusalem, Athanasius for Athos, and John Climacus for Sinai) ${ }^{13}$, hinting at a similar concern for claiming a filiation with the most revered spiritual centres of the Orthodoxy. The insertion of St. Sylvester in Moldavian programs might be paralleled with Serbian examples; the illustration of Roman popes (most frequently Sylvester, but sometimes also Leo and Martin) represents a peculiar feature of the Serbian medieval wall paintings. In Sopoćani ${ }^{14}$, Leo is depicted towards the northern end of the procession, followed by local saints (Sabbas II and Arsenius), while at Lesnovo ${ }^{15}$, he accompanies Sylvester at the southern extremity. On the one hand, Sylvester stands alone at Karan ${ }^{16}$, Prokuplje ${ }^{17}$ and Manasja ${ }^{18}$, but one must highlight that he never takes a leading position, as in Pătrăuţi and Popăuţi. Martin, on the other hand, appears in the northern pastophorion at Matejc ${ }^{19}$.

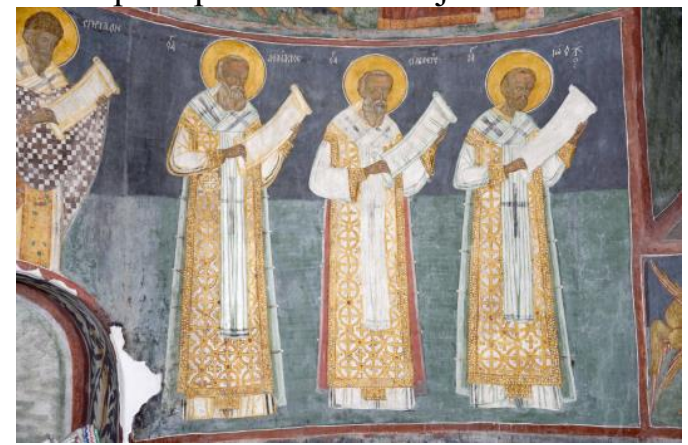

Fig. 1 Pătrăuți. Apse, Sts. John Chrysostom, Sylvester, Athanasius, and Spyridon

\footnotetext{
${ }^{13}$ André Grabar, "Un cycle des capitales chrétiennes dans l'art moldave du XVI siècle", in Jahrbuch der Österreichischen Byzantinistik, t. 21 (1972), pp. 125-130.

${ }^{14}$ Nikolaj Okunev, "Les peintures murales à l'église de Sopoćani”, in Byzantinoslavica, t. 1 (1929), p. 120 sqq, Gabriel Millet and Anatole Frolow, La peinture du moyen age en Yougoslavie, II, de Boccard, Paris, 1957, pl. 1 (3-4), 2-3, 4 (4), 98 (1), Vojislav J. Đurić, Sopoćani, Prosveta, Belgrade, 1963, pp. 54, 112, ill. I-II, B. Todić, "L'Apôtre André et les Archevêques Serbes sur les fresques de Sopoćani”, in Byzantion, t. 72 (2002), pp. 465-474, ill. 2-3.

${ }^{15}$ Smiljka Gabelić, Manastir Lesnovo. Istorija i slikarstvo, Stubovi kulture, Belgrade, 1998, pp. 69, 273, pl. 18-23.

${ }^{16}$ Milan Kašanin, "Bela crkva Karanska", in Starinar, ser. 3, t. 4 (1926-1927), pp. 187 sqq, pl. $11,39,40$.

${ }^{17}$ Dušan Tasić, "Les peintures de l'église médiévale de Prokuplje", in Zbornik za Likovne Umetnosti Matice Srpski, t. 3 (1967), pp. 129 sqq, pl. 2-3.

${ }^{18}$ B. Todić, Manastir Resava, Agencija "Draganić", Belgrade, 1995, pp. 57-61, 149, 153, pl. 32, 56-59. 61, 101, 107.

${ }^{19}$ Elizabeta Dimitrova, Manastir Matejče, Kalamus, Skopje, 2002, pp. 107 sqq, 278, 285, 301, 315, pl. 18-21.
} 


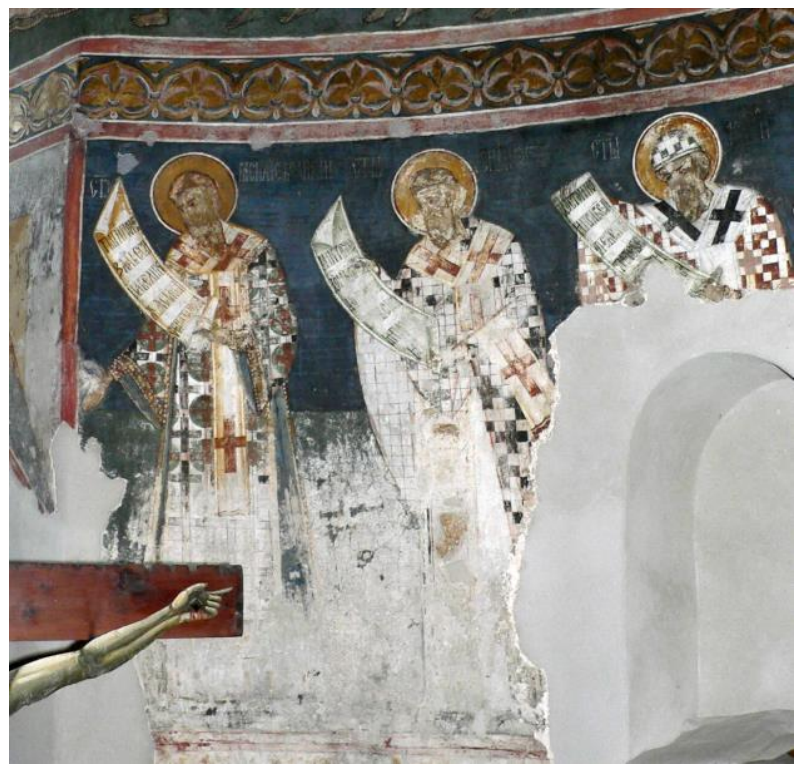

Fig. 2 Popăuți. Apse, Sts. Basil, Sylvester, and Cyril

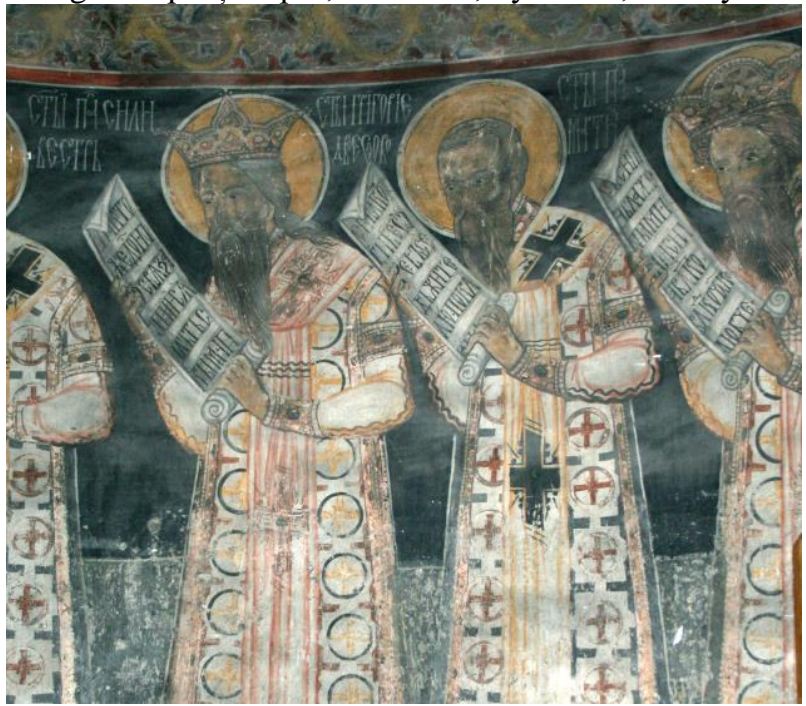

Fig. 3 Dobrovăț Monastery. Apse, Sts. Sylvester, Gregory, and Martin

The presence of Roman Popes in the economy of apsidal programmes raises serious issues, in the light of an observation made by Christopher Walter who pointed out synthetically that these iconographies avoid all secondary or problematic aspects ${ }^{20}$. For instance, the role played by the emperors in the salvific plan, alongside other themes related to the

${ }^{20}$ Christopher Walter, Art and Ritual of the Byzantine Church, Variorum Publications, London, 1982, p. 221. 
oikumene, is usually relegated to the narthe ${ }^{21}$. A similar situation is met with the themes connected with confessional controversies, though the most outstanding authors of mystagogical writings, Nicholas of Andida and Nicholas Cabasilas, were at the same time very active in the polemic against the Latins. Given this tendency of the Byzantine iconography, the Roman Popes were not a popular choice, a fact that singles out even more the case of the southern pastophorion from Ohrid. Walter quotes alongside this example the appearances of Sylvester in Saint Sofia from Kiev, Hosios Loukas, Daphni, Saint Nicholas Orphanos from Salonic, Bela Crkva, Staro Nagorično and Dečani ${ }^{22}$. In the last two monuments, he is accompanied by Leo. One must add to this corpus the iconography of the Northern pastophorion in the church of St. Nicholas from Curtea de Argeş (Fig. 4), where saint Sylvester is depicted alongside Peter of Alexandria, Spyridon of Trimythous, John the Almoner of Constantinople and a fourth unidentified bishop ${ }^{23}$. From a statistic point of view, nonetheless, Walter was right to consider that the Popes of Rome did not represent a popular iconographic choice throughout the middle and late Byzantine periods ${ }^{24}$.

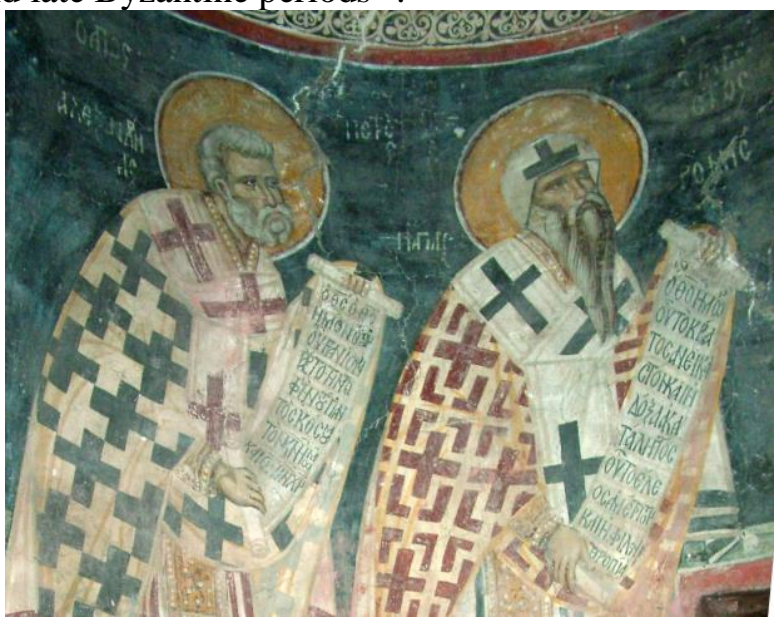

Fig. 4 Curtea de Argeș, Sts. Sylvester and Peter of Alexandria

\footnotetext{
${ }^{21}$ Ibidem, pp. 221-222.

22 Ibidem, pp. 222 and n. 307, commenting also the situation of Pope Leo (scarcely represented) and Martin, Agatho or Gregory Dialogus, almost absent from monumental programs.

${ }^{23}$ Daniel Barbu, Pictura murală din Țara Românească în secolul al XIV-lea [The Wall Painting from Țara Românească in the $14^{\text {th }}$ century], "Meridiane" Publishing House, Bucharest, 1986, p. 53, iconographic inventory under numbers 62-66. The author does not speculate on this peculiar choice. On the scroll of Pope Sylvester: "Lord, our God, Whose dominion is incomparable and glory incomprehensible; Whose mercy is immeasurable, and love for mankind [ineffable]" (secret prayer of the first antiphon).

${ }^{24}$ See, more recently, Chara Konstantinidi, Ho Melismos: hoi sylleitourgountes hierarches kai hoi aggelloi-diakonoi mprosta stēn Hagia Trapeza me ta timia dōra è ton eucharistiako Christo, Thessaloniki, Kentro Byzantinōn Ereunōn, 2008.
} 
However, the Moldavian examples quoted earlier, as well as the situation in Curtea de Argeş, have nonetheless been extended during the $16^{\text {th }}$ and $17^{\text {th }}$ centuries in Wallachia through the practice of including a series of iconic portraits of Roman Popes at the base of the drum. Their placement between the iconography of the drum and the four evangelists from the pendentives brings forth a vigorous ecclesiological inference, pointing at the role played by the successors of Peter in the accomplishment of the divine providence. Thus, in the funerary parekklesion of Cozia ${ }^{25}$, this row is composed by saints Sylvester, Vigilius (inscribed as 'Vergilius'), Gregory, Celestine and Agatho (Fig. 5). The first two popes hold open books (that of Sylvester miraculously floating above his trunk, as the bishop blesses with both his hands). Its text is worn out, but one can still read the book held by the other pope: "And in one Lord Jesus Christ, the only-begotten Son of God." The popes from Cozia, led by Sylvester and Vigilius, recite the Nicene Creed $^{26}$. One must notice that the popes' headgears are tiaras or royal crowns, the letter choice reminding the Moldavian practice, as the instances from Dobrovăţ, from Voroneţ or from the ecumenical councils represented at Arbore show this peculiar royal feature. A similar iconography is displayed in the catholicon from Snagov monastery ${ }^{27}$, doubled nonetheless by a most spectacular selection of Roman Popes for the prothesis chapel (Fig. 6), echoing the situation met earlier at St. Nicholas from Curtea de Argeș. At Snagov, the centre of the small apse is occupied by an altar table surmounted by the dove of the Holy Spirit encircled by an eight-rayed glory; this theophany is flanked by the officiating bishops: Anthimus of Nicomedia, Pope Leo, Pope Sylvester, Pope Agatho ${ }^{28}$, Hierotheos, Dionysius Areopagitus, and Timotheos. The prayers inscribed on the scrolls held by

\footnotetext{
${ }^{25}$ Carmen Laura Dumitrescu, Pictura murală din Țara Românească în veacul al XVI-lea [The Wall Painting in Tara Românească in the $16^{\text {th }}$ century], Meridiane Publishing House, Bucharest, 1978, pl. 9-11; Ioana Iancovescu, "Picturile de la bolnița mânăstirii Cozia" [The Paintings from the Hospital of Cozia monastery], in Studii şi Cercetări de Istoria Artei [Studies and Research in Art History], new ser., t. 2 (2012), pp. 161-214.

${ }^{26}$ I. Iancovescu, "Picturile" ["Paintings"], p. 164, 167 (iconographic inventory, under "Naos", no. 5) and fig. 21 on p. 181.

${ }^{27}$ See more recently Atanasia Văetiși, "Ansamblul pictural al bisericii Mănăstirii Snagov" ["The Piuctural Ensemble of the Church of Snagov Monastery], in Mănăstirea Snagov: istorie şi artă [Snagov Monastery: History and Art], "Cuvântul vieții”" Publishing House, Bucharest, 2011, p. 95. Conf. C. L. Dumitrescu, "Deux églises valaques décorées au XVIe siècle: Snagov et Tismana" [Two Wallachian Churches Decorated during the $16^{\text {th }}$ century: Snagov and Tismana], in Revue Roumaine d'Histoire de l'Art, t. 10 (1973), no. 1-2.

${ }^{28}$ All standing iconic portraits preserve, alongside the painted tituli, the sgraffiti incised by the painters; the portrait of Agatho has lost the painted inscription, but its sgraffito is still legible.
} 
popes Sylvester and Agatho display the secret prayers for incensing ${ }^{29}$ and for the completion of the prothesis rite ${ }^{30}$.

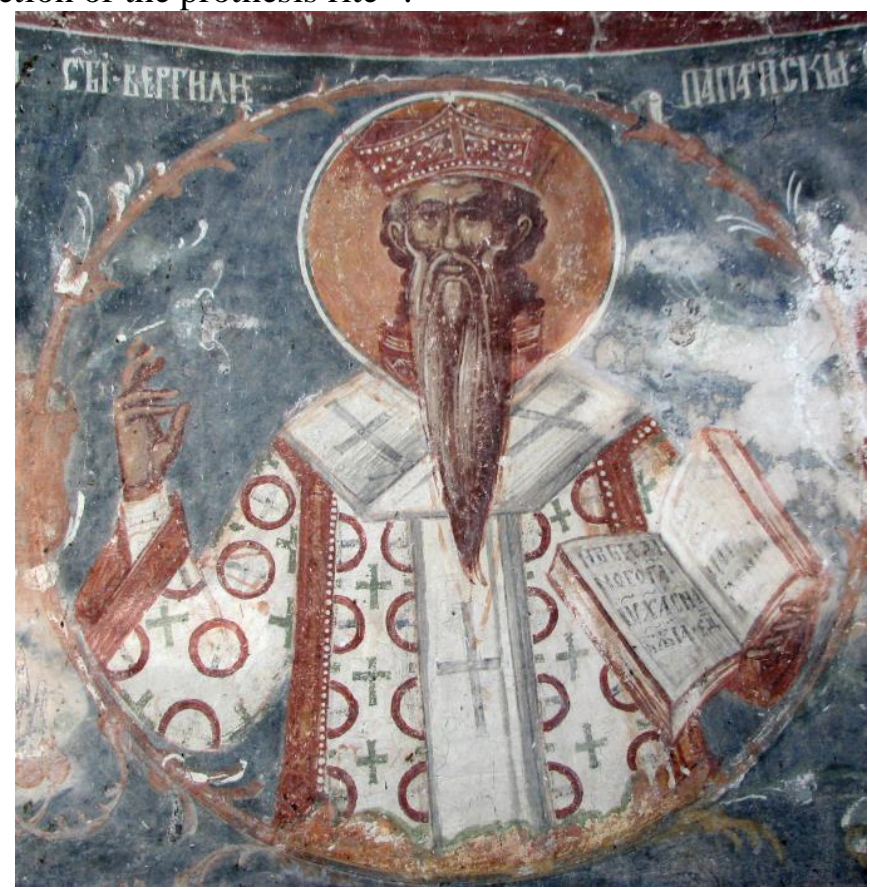

Fig. 5 Cozia, funerary parekklesion. Pope Vegilius

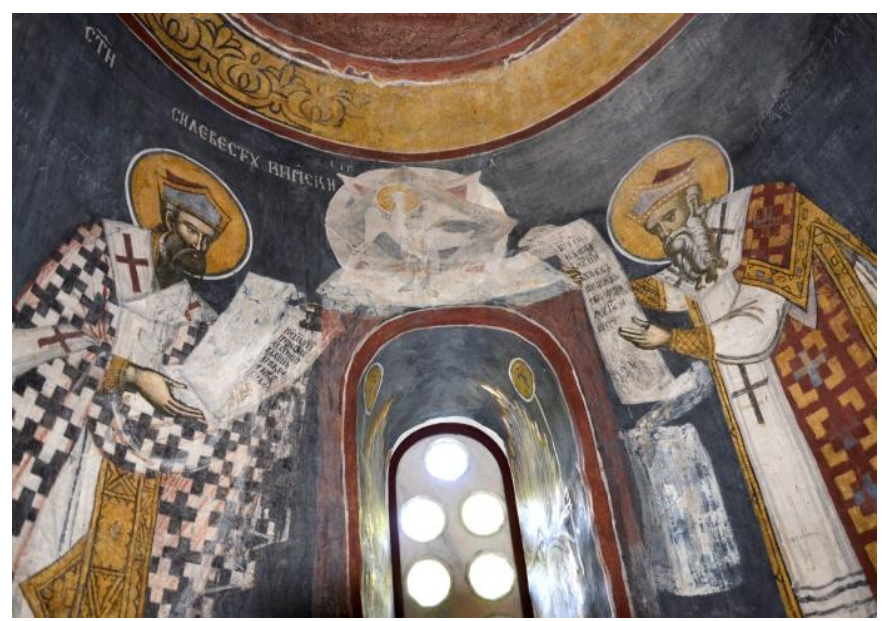

Fig. 6 Snagov Monastery, prothesis chapel

\footnotetext{
${ }^{29}$ On the scroll of Pope Sylvester: "We offer You incense, O Christ our God, for a perfume of [spiritual] fragrance; receive it [upon Your heavenly Altar and send down upon us in return the grace of Your all-Holy Spirit]".

${ }_{30}$ On the scroll of Pope Agatho: "O God, our God, who didst send forth the heavenly Bread, the food of the whole world, our Lord [and God Jesus] Christ".
} 
A renewed interest in the portrayal of Roman Popes is registered in the Wallachian wall paintings from the $17^{\text {th }}$ century, beginning with the reign of Matei Basarab. Thus, at Topolniţa ${ }^{31}$, Sylvester holds the second to last position in the southern half of the apsidal procession, while at Scăueni ${ }^{32}$ he appears alongside Gregory, and in Creţuleşti ${ }^{33}$, he is figured alongside Cyril of Alexandria; one must also notice that in the row of medallions above the procession, in the corresponding position to Sylvester is represented Ambrose of Mediolanum. In the same interval, at Arnota, six popes (all labelled as papareski, a shortened version for the traditional epithet papa rymski, present in the wall paintings of the $16^{\text {th }}$ century) occupy the arch between the apse and the dome ${ }^{34}$ : Pegasios ${ }^{35}$ (?), Sylvester, Bucolus ${ }^{36}$, Vigilius, Martin, and Agatho (Fig. 7). Exceptionally enough, in this monument, the Roman Popes are figured a second time in the narthex, on the transversal arch (Fig. 8), which displays the busts of Bucolus, Leo, Andrew ${ }^{37}$, Celestine, Adrian, Martin, and Dionysius ${ }^{38}$.

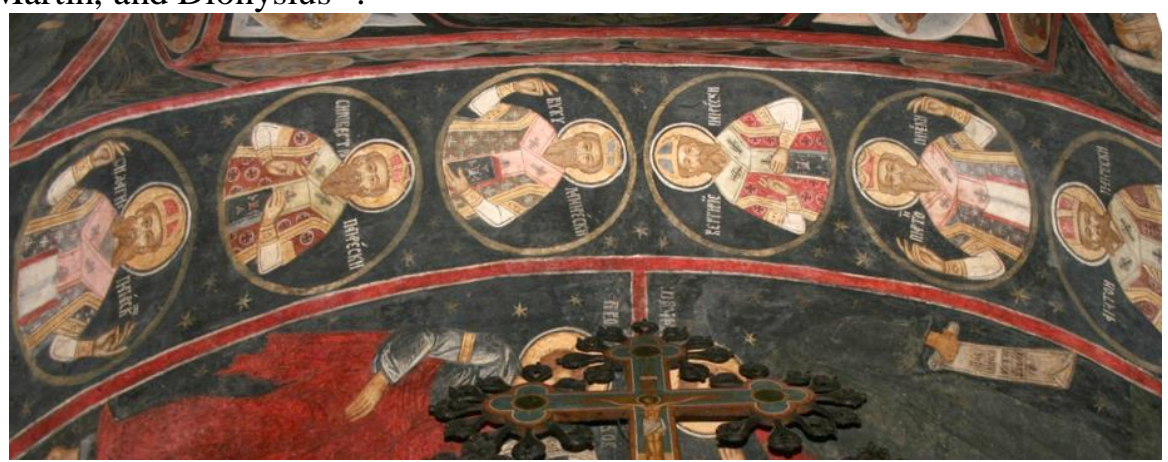

Fig 7 Arnota Monastery. Naos, Eastern arch

\footnotetext{
${ }^{31}$ Cornelia Pillat, Pictura murală în Țara Românească în epoca lui Matei Basarab [Mural Painting in Țara Românească during the time of Matei Basarab], "Meridiane" Publishing House, Bucharest, 1980, p. 24, iconographic inventory under no. 32.

32 Ibidem, p. 32, iconographic inventory, under no. 5.

${ }^{33}$ Ibidem, p. 34, iconographic inventory, under no. 40.

${ }^{34}$ Conf. ibidem, p. 19, iconographic inventory, under nos. 19-22: Agatho, Vucu (sic), Eravest (sic), Pegasius.

${ }^{35}$ The inscription is disfigured by the clumsy restoration, so the lecture of Cornelia Pillat could be trusted. However, there is no pope listed with this name; Pegasius was one of the priests martyred in Isfahan by the Persian king Sapor II (alongside Acindynus, Aphthonius, Elpidephorus, and Anempodistus). An alternate reading could nonetheless indicate Pope Damasus.

${ }^{36}$ There is no pope listed under this name, St. Bucolus, disciple of Apostle John, was bishop of Smyrna.

${ }^{37}$ Despite the clear inscription, there is no evidence for a pope bearing this name, leaving aside the fictional "Jewish Pope".

${ }^{38}$ Conf. Pillat, Pictura murală [Wall Painting], p. 19, iconographic inventory, under nos. 108115: portraits of patriarchs.
} 


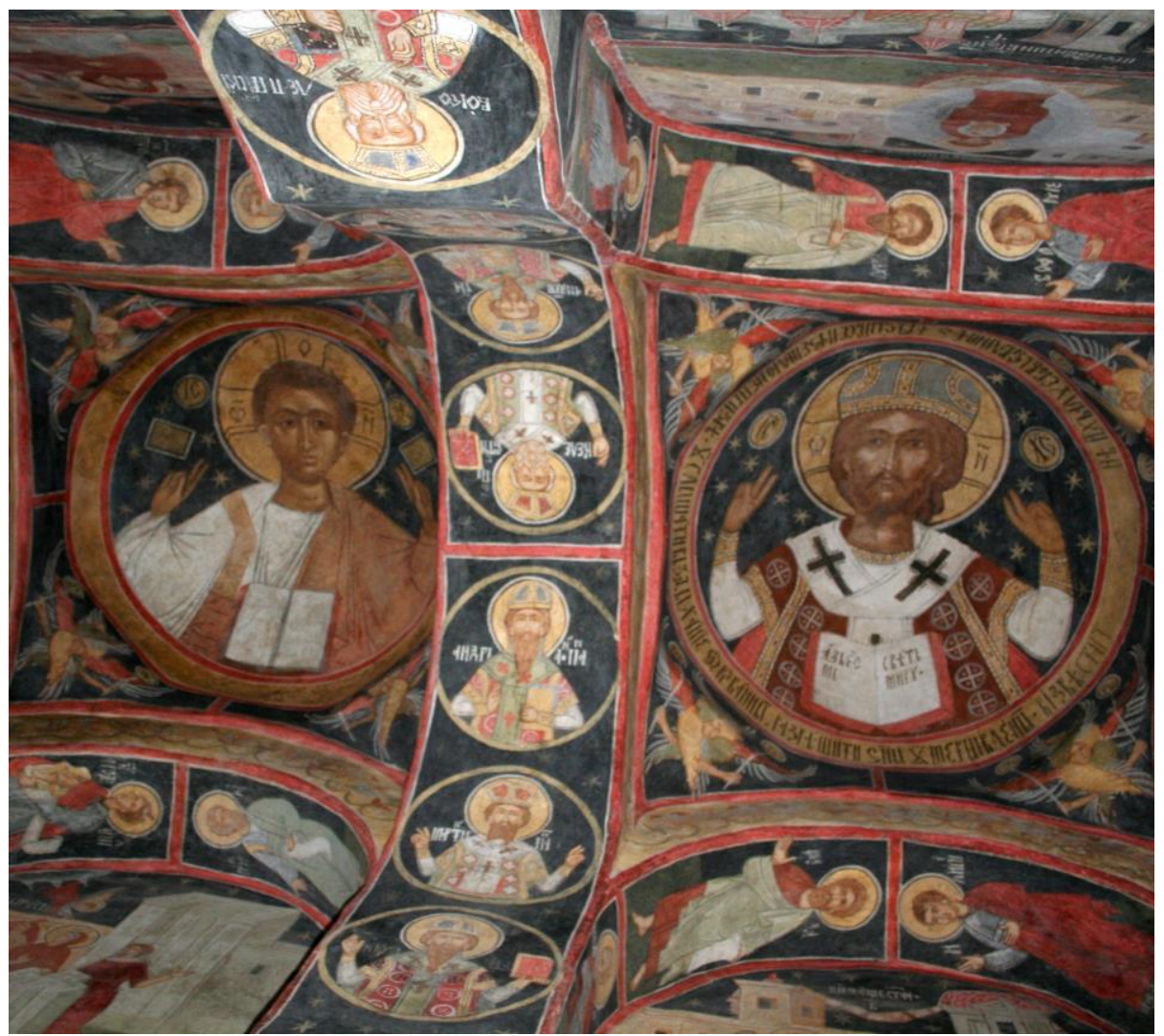

Fig. 8 Arnota Monastery. Narthex, transversal arch

The most significant moment for this peculiar selection of saintly bishops is registered during the reign of Constantin Brâncoveanu; in the perimeter of Vâlcea district only ${ }^{39}$, at this time, several monuments display the familiar row of medallions at the base of the drum, including a large number of Roman Popes (in the following lists, footnotes will indicate the plausible identifications for saints who were surely not titulars of this see). At $\mathrm{Mamu}^{40}$, this selection includes saints Clemens, Martin, Julius, Juvenal ${ }^{41}$, Constantine, Simeon ${ }^{42}$, Eutychius ${ }^{43}$, Leo, Gregory, Eleutherius, Theodotus ${ }^{44}$,

\footnotetext{
${ }^{39}$ Corina Popa, Ioana Iancovescu, Vlad Bedros, Elisabeta Negrău, Repertoriul picturii murale brâncovenești: I [The Repertory of Wall Painting having a Brâncovenesc style], Vâlcea Department, The Publishing House of the National University of Arts, Bucharest, 2008.

${ }^{40}$ Repertoriul [The Repertory], p. 172, II.5.

${ }^{41}$ Bishops with this name are listed for the dioceses of Jerusalem and Narni; Juvenal of Jerusalem was the first bishop to receive the patriarchal dignity, after the Council of Chalcedon.

${ }^{42}$ The only pope with this name held the see of Alexandria.

${ }^{43}$ Patriarch of Constantinople.

${ }^{44}$ Bishop of Laodicea.
} 
Meletius $^{45}$, Capiton ${ }^{46}$, Parthenius ${ }^{47}$, Hippolytus, Peter ${ }^{48}$, Innocent, Boniface, and Sylvester. At Polovragi ${ }^{49}$, the saints selected for this register are Clemens (Fig. 9), Sylvester, Eleutherius, Charalampos ${ }^{50}$, Acepsimus, Aeithalas ${ }^{51}$, Meletius ${ }^{52}$, Stephen, Agapetus, Eusebius, Martin, Eutychius ${ }^{53}$, Dionysus, Nicander $^{54}$, and Joannicius ${ }^{55}$. In the church of Surpatele Monastery ${ }^{56}$, the saints depicted at the base of the drum are $\mathrm{Jacob}^{57}$, Liberius, Apollonius ${ }^{58}$, Agapetus, Stephen, Flavius ${ }^{59}$, Sixtus, Gregory, Alexander, Boniface, Innocent, Celestine, Martin, Agapetus (Fig. 10), Agatho, Adrian, Stephen, Clemens, and Sylvester. The church from Fedeleşoiu ${ }^{60}$ displays the following saints in this area: Gregory, Sylvester, John, Germanus, Proclus, Metrophanes $^{61}$, Cyril $^{62}$, Methodius ${ }^{63}$, Sophronius ${ }^{64}$, Athanasius ${ }^{65}$, Nicephorus, Eutychius $^{66}$, John ${ }^{67}$, Stephen, and Basil ${ }^{68}$. In the catholicon of Govora ${ }^{69}$ the papal selection (preserved inscriptions include the title 'pope') comprises Leo, Agapetus, Liberius, Clemens, Nicholas ${ }^{70}$, Gregory, Boniface, Zosimus, Thomas $^{71}$, Celestine, Adrian, and Agatho. At Ocnele Mari ${ }^{72}$, the medallions depict 'popes' (same epigraphic peculiarity as earlier at Govora) Sylvester, Gregory, Alexander, John ${ }^{73}$, Peter, Adrian, Flavius ${ }^{74}$, Jacob ${ }^{75}$, and

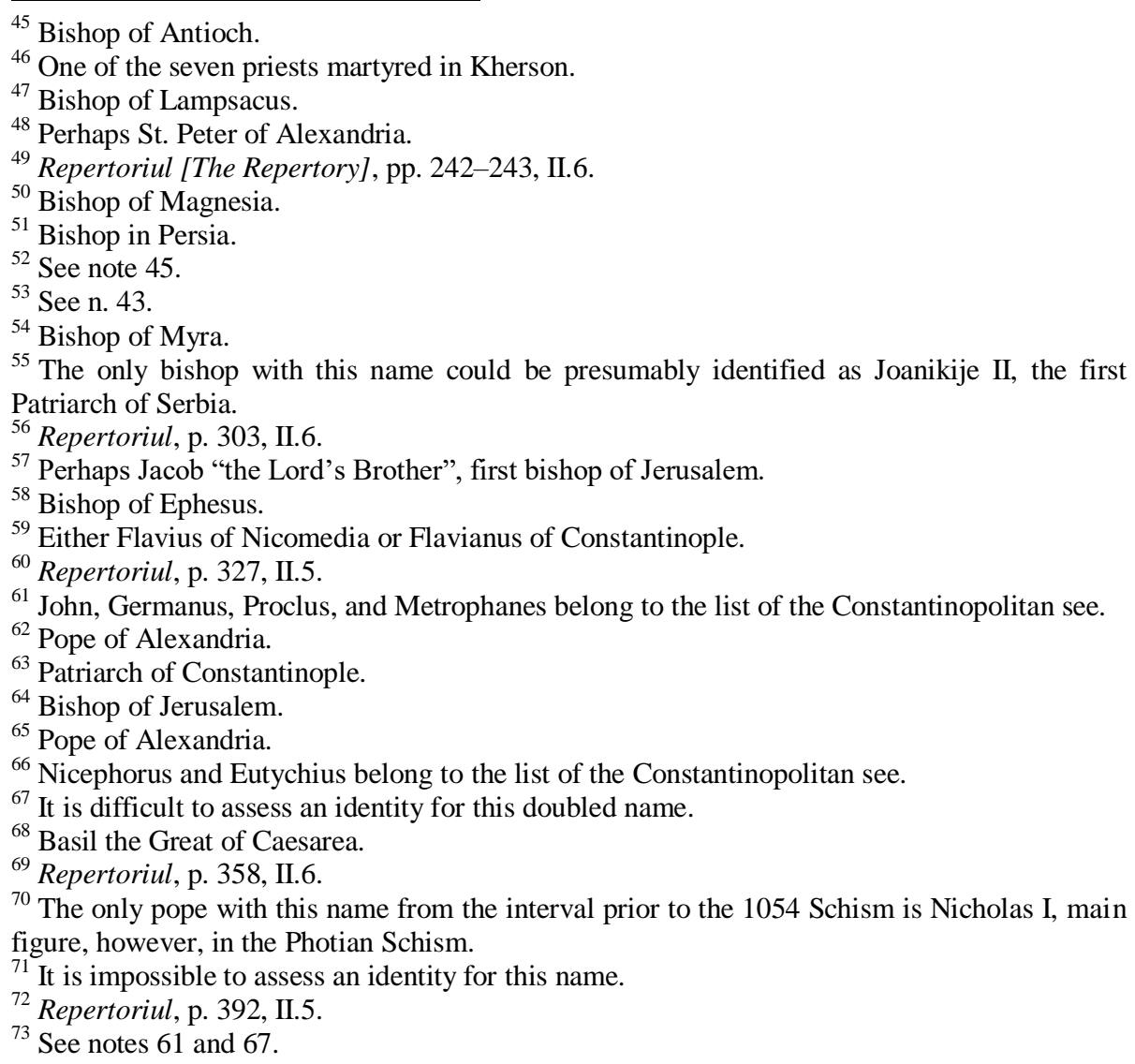


Germanus $^{76}$. Eventually, the church of Sărăcineşti Monastery ${ }^{77}$ includes in this iconographic register 'popes' Sylvester, Nicephorus, Paul, Methodius ${ }^{78}$, Alexander, Leontius ${ }^{79}$, Eutychius ${ }^{80}$, Meletius ${ }^{81}$, Paul, Leo, Metrophanes, and Germanus ${ }^{82}$. The possible survival of this practice in post-Brâncovan ensembles could be proved by further examinations.

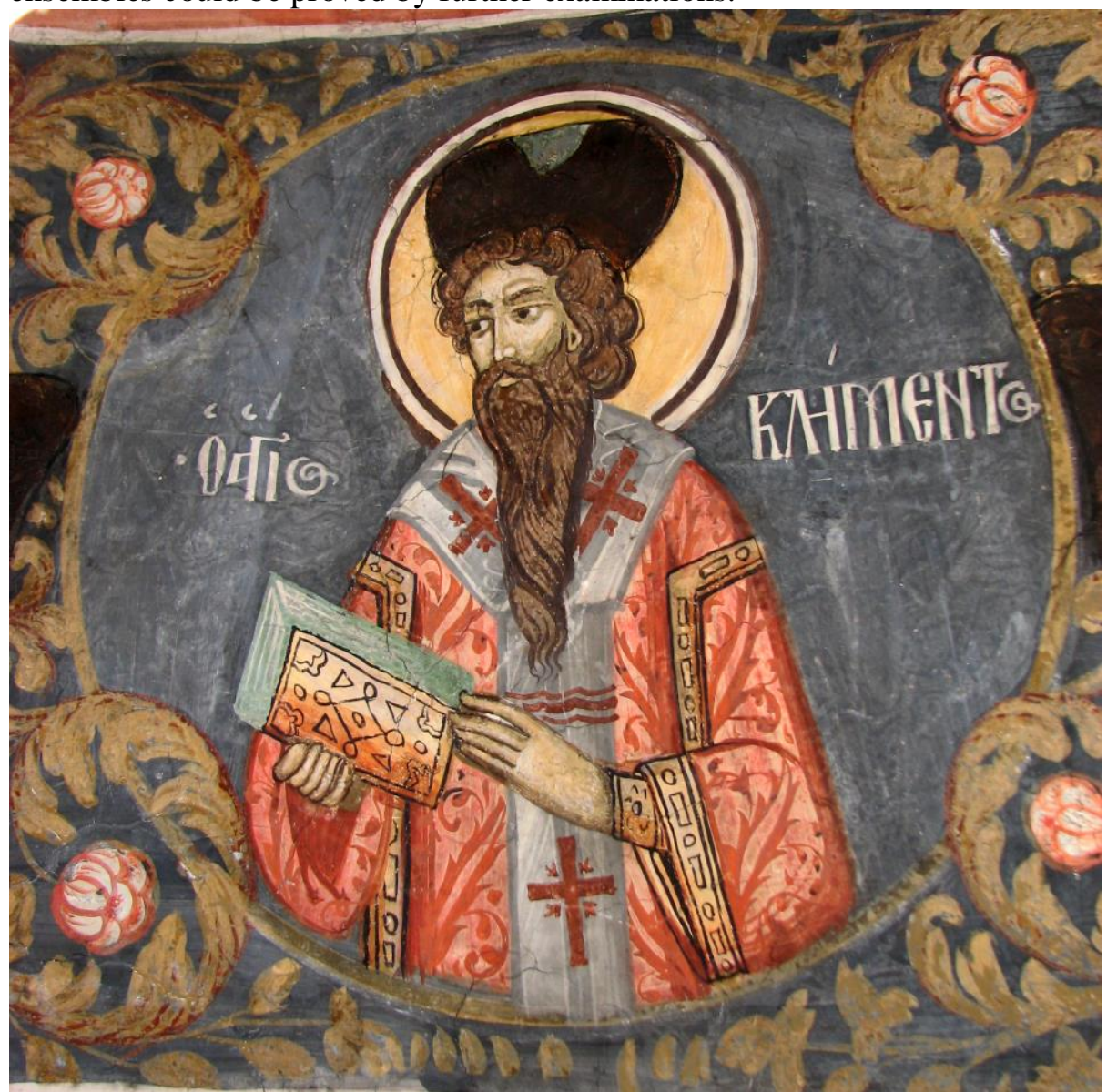

Fig. 9 Polovragi Monastery. Pope Clemens

\footnotetext{
${ }^{74}$ See note 59

${ }^{75}$ See note 57

${ }^{76}$ Patriarch of Constantinople.

${ }^{77}$ Repertoriul [The Repertory], p. 414, II.6.

${ }^{78}$ Nicephorus, Paul and Methodius belong to the list of the Constantinopolitan see.

${ }^{79}$ Bishop of Caesarea.

${ }^{80}$ See note 43.

${ }^{81}$ See note 45.

${ }^{82}$ See notes 61 and 76.
} 


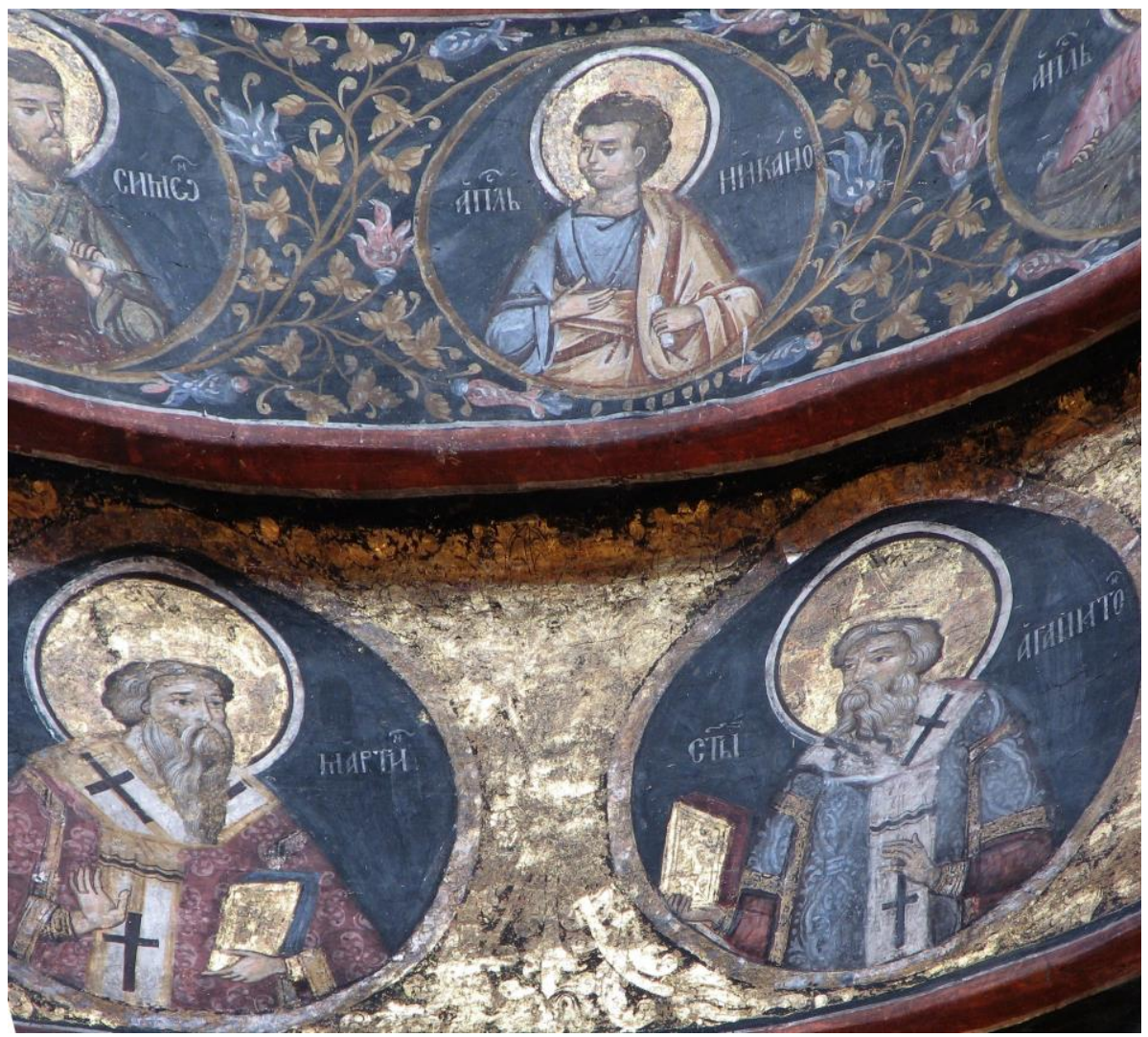

Fig.10 Surpatele Monastery. Popes Martin and Agapetus

As one would expect, these programmes are informed by the tradition set by the ensemble of Hurezi; indeed, in the catholicon, the parallel between the Old and the New Rome is expressed by the mirroring of two rows of archbishops, depicted on the two halves of the circumference, at the base of the drum ${ }^{83}$ (Constantinople and other major eastern centres of Patristic age: John Chrysostom, Basil the Great, Athanasius, Cyril ${ }^{84}$, Germanus, Proclus, Methodius, Nicephorus, Metrophanus; Rome: Sylvester, Martin, Leo, Alexander, Agapetus, Liberius, Clemens, Adrian, Agatho, Celestine, Stephen, Hippolytus, Gregory; Constantinople again: Paul the Confessor, Eutychius, Gregory the Theologian). This program is reinstated in the hermitage of Saint Stephen ${ }^{85}$ (Basil, Gregory, Martin, Therapon ${ }^{86}$,

\footnotetext{
${ }^{83}$ Repertoriul [The Repertory], p. 63, IV.8.

${ }^{84}$ Basil the Great held the See of Caesarea, while Athanasius and Cyril belong to the See of Alexandria.

${ }^{85}$ Repertoriul, p. 217, II.6.

${ }^{86}$ Bishop in Cyprus.
} 
Clemens, Patricius ${ }^{87}$, Sylvester, Nicephorus, and Athanasius ${ }^{88}$ ), but not necessarily in the hermitage of the Holy Apostles ${ }^{89}$, where the series of popes and patriarchs is displayed on the upper parts of the Northern and Southern walls (Sylvester, Nectarius ${ }^{90}$, Modestus ${ }^{91}$, Athanasius, Cyril ${ }^{92}$, Nicephorus ${ }^{93}$, Gregory and Spyridon Trimythous).

To sum up this issue, one must be mindful of two aspects implied in the popularity of the Roman Popes in the post-Byzantine iconography within the Romanian territory: on the one hand, the leading figure, as in Byzantium, seems to be Pope Sylvester, and on the other, there is also a narrative component for the devotion addressed to this saint, expressed by episodes from his life that become entangled with the hagiographic material concerning saint Constantine the Great. Two of these episodes are even illustrated in local iconographies, one in Moldavia and the other one in Wallachia. At Bălineşti, the narthex includes a large cycle of the miracles worked by the Archangels, and, among them, the baptism of Constantine by St. Sylvester ${ }^{94}$ (Fig. 11); this episode appears in the Late Byzantine redactions of the life of Constantine, which were received Moldavia through the Slavonic version compiled by Patriarch Euthymius of Tărnovo ${ }^{95}$. The second instance is represented by the illustration of the dispute between St. Sylvester and Rabbi Zamvri in the cycle of Saint Constantine from the narthex of Hurezi Catholicon (Fig. 12). There is no evidence that this episode from the life of Sylvester was ever integrated into the life of Constantine ${ }^{96}$.

\footnotetext{
${ }^{87}$ Bishop of Prusa.

${ }^{88}$ See note 84.

${ }^{89}$ Repertoriul, pp. 198-199, II.10.

${ }^{90}$ Patriarch of Constantinople.

${ }^{91}$ Bishop of Jerusalem.

${ }^{92}$ See note 84 .

${ }^{93}$ See note 66.

${ }^{94}$ The cycle was first signalled by Sorin Ulea, "La peinture extérieure moldave: où, quand et comment est-elle apparue"[«Moldavian External Painting: where, when and how it appeared »], in Revue Roumaine d'Histoire, t. 23 (1984), no. 4, p. 286, note 12.

${ }_{95}$ Gheorghe Mihăilă, "Tradiția literară constantiniană de la Eusebiu al Cezareei la Nichifor Calist Xanthopoulos, Eftimie al Tîrnovei și domnii țărilor române” [« Literary tradition during the time of Constantin from Eusebiu of Caesarea to Nichifor Calist Xanthopoulos, Eftimie of Tîrnova and the rulers of Romanian countries», in Cultură şi literatură română veche in context european: studii și texte [Culture and Old Romanian Literature in the European Context: studies and texts], The Scientific and Encyclopedic Publishing House, Bucharest, 1979, pp. 217-380.

${ }^{96}$ Ioana Iancovescu, "Biserica Sf. Împăraţi: pictura" ["The Church of the Saint Emperrors: Painting"], in Repertoriul [The Repertory], pp. 50-51.
} 


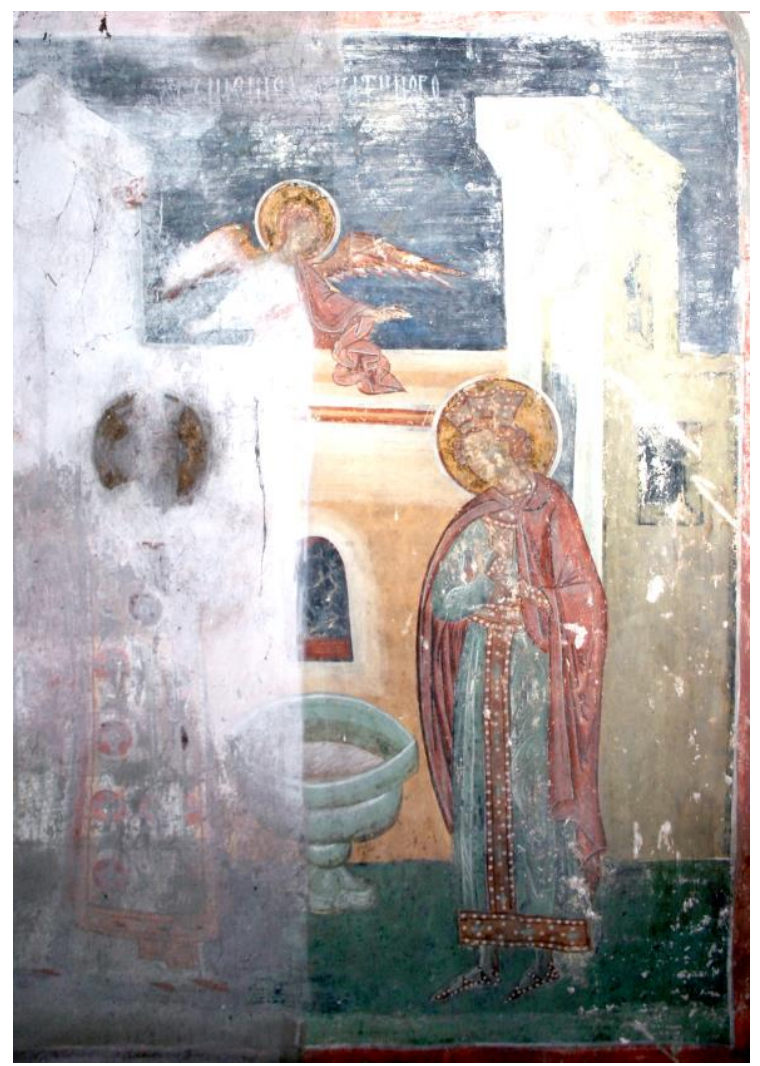

Fig.11 Bălinești. Narthex, Baptism of St. Constantine

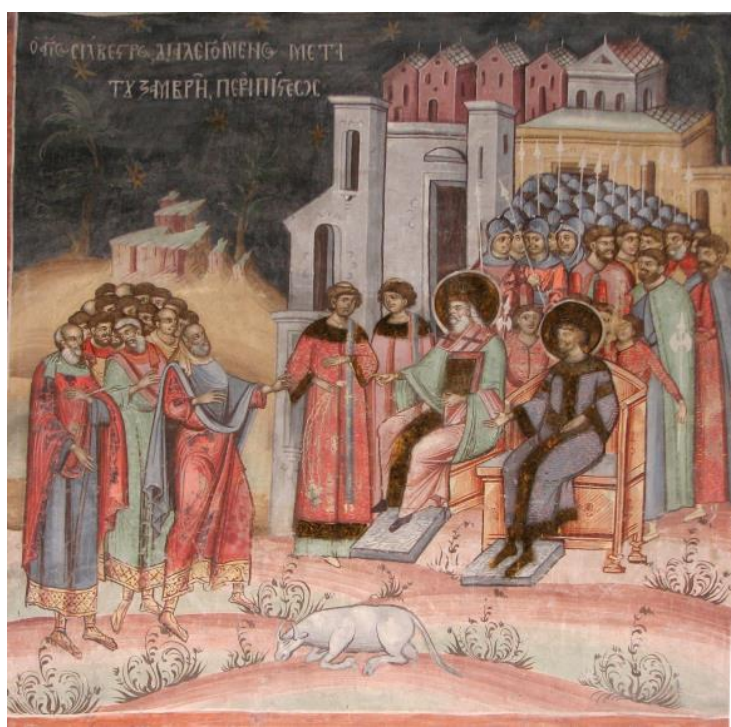

Fig.12 Hurezi Monastery. Narthex, Dispute of St. Sylvester with Zamvri 
These iconographic contexts invite to an evaluation of the parallelism between the two protagonists, the emperor and the pontiff, as model for the ideal balance between the secular and spiritual authorities. In my opinion, the popularity of Sylvester and, alongside him, of several or many other Roman Popes, might be seen as a visual expression of the fidelity manifested towards the Byzantine heritage of symphoneia but also as a claim to the plenitude of the apostolic tradition for the local church, which expressed its "pedigree" through this inclusion of archbishops from each of the prestigious sees of the Pentarchy - among which Rome never lost its leading role.

However, the appropriation of the Roman Popes as a crucial part of the selection of saintly bishops participating in the iconographic programs of Late and Post-Byzantine pictorial practice should be equally interpreted in the light of the fervent polemic against the "Latin Church", entering therefore within the broader 'polemical quotations' recently conceptualized by Ágnes $\mathrm{Kriza}^{97}$. As I showed, the local Post-Byzantine iconographies seldom display Popes of Rome commemorated in the Byzantine ritual as sources of legitimation within the Orthodox oikoumene. More strikingly, in the $17^{\text {th }}$ century (when the title of 'pope' was arguably pointing first of all to the Roman pontiff rather than to the memory of the Alexandrian Popes), this epithet is sometimes bestowed upon saintly bishops who obviously belong to the other sees of the Pentarchy (the 'New Rome', Antioch, Jerusalem) or to crucial spiritual centres of Early Christianity. The most conspicuous turn in this iconography belongs to the $16^{\text {th }}$ century, when the Popes are placed at the base of the drums to recite the Nicene Creed (thus hinting at the Filioque dispute) or take part in the rite of prothesis, as witnesses of the descend of the Holy Spirit upon the altar table (alluding henceforth both to the Liturgical dispute regarding the offertory, and equally to the theological polemic concerning the eucharistic transubstantiation).

Kriza:

Such practices echo indeed the 'polemical quotations' described by

What we see here, however, is a visual counterpart to written religious polemic: this is visual polemic, a pictorial use of the rules of rhetoric. In order to challenge an idea, the polemicist, that is, the painter, quotes his opponent: he takes an iconographic element or motif from the representation he wants to challenge, in order to make the target of the polemic recognisable. [...] The Orthodox painters quoted the Western pictorial elements, but they also modified them and put them into a new, transformative context, thus juxtaposing their own position and counterclaim $^{98}$.

${ }^{97}$ Ágnes Kriza, "The Russian Gnadenstuhl", in Journal of the Warburg and Courtauld Institutes, t. 79 (2016), pp. 79-130, esp. 122-128.

${ }^{98}$ Ibidem, pp. 122-123. 


\section{List of illustrations:}

Fig. 1 Pătrăuți. Apse, Sts. John Chrysostom, Sylvester, Athanasius, and Spyridon

Fig. 2 Popăuți. Apse, Sts. Basil, Sylvester, and Cyril

Fig. 3 Dobrovăț Monastery. Apse, Sts. Sylvester, Gregory, and Martin

Fig. 4 Curtea de Argeș, Sts. Sylvester and Peter of Alexandria

Fig. 5 Cozia, funerary parekklesion. Pope Vegilius

Fig. 6 Snagov Monastery, prothesis chapel

Fig. 7 Arnota Monastery. Naos, Eastern arch

Fig. 8 Arnota Monastery. Narthex, transversal arch

Fig. 9 Polovragi Monastery. Pope Clemens

Fig. 10 Surpatele Monastery. Popes Martin and Agapetus

Fig. 11 Bălinești. Narthex, Baptism of St. Constantine

Fig. 12 Hurezi Monastery. Narthex, Dispute of St. Sylvester with Zamvri

\section{Bibliography:}

Barbu, Daniel, Pictura murală din Țara Românească în secolul al XIV-lea [The Wall Painting from Țara Românească in the $14^{\text {th }}$ Century], "Meridiane" Publishing House, Bucharest, 1986.

Bedros, Vlad, "Selecția sfinților ierarhi în absidele moldovenești (secolele XVXVI)" ["The Selection of Saint Hierarchs in Moldavian Apses $\left(15^{\text {th }}-16^{\text {th }}\right.$ c."], in POLYCHRONION. Profesorului Nicolae-Șerban Tanașoca la 70 de ani [POLYCHRONION. To Professor Nicolae-Șerban Tanașoca on his $70^{\text {th }}$ anniversary], The Publishing House of the Romanian Academy, Bucharest, 2012, pp. 65-75.

Cvetković, Branislav, "Intentional Asymmetry in Byzantine Imagery: The Communion of the Apostles in St. Sophia of Ohrid and Later Instances", in Byzantion, t. 76 (2006).

Dimitrova, Elizabeta, Manastir Matejče [The Monastery of Mateič], Skopje, Kalamus, 2002.

Dumitrescu, Carmen Laura, "Deux églises valaques décorées au XVIe siècle: Snagov et Tismana", in Revue Roumaine d'Histoire de l'Art, t. 10 (1973), no. 1-2.

Dumitrescu, C. L., Pictura murală din Țara Românească în veacul al XVI-lea [Wall Painting in Wallachia in the $16^{\text {th }} \mathrm{c}$.], Meridiane Publishing House, Bucharest, 1978.

Đurić, Vojislav J., Sopoćani, Prosveta, Belgrade, 1963.

Falkenhausen, Vera von, "San Pietro nella religiosità bizantina", in Bisanzio, Roma e l'Italia nel'Alto Medioevo: Settimane di studio del Centro Italiano di Studi sull'Alto Medioevo 34, 3-9 aprile 1986, II, Presso la sede del Centro, Spoleto, 1988.

Gabelić, Smiljka, Manastir Lesnovo. Istorija i slikarstvo [The Monastery of Lesnovo. History and Art], Stubovi kulture, Belgrade, 1998.

Grabar, André, "Un cycle des capitales chrétiennes dans l'art moldave du XVIe siècle", in Jahrbuch der Österreichischen Byzantinistik, t. 21 (1972).

Iancovescu, Ioana, "Picturile de la bolnița mânăstirii Cozia" ["The Paintings from the Hospital Church of Cozia Monastery], in Studii și Cercetări de Istoria Artei [Studies and Research in Art History], new ser., t. 2 (2012). 
Janin, Raymond, La géographie ecclésiastique de l'Empire Byzantin. Première partie: Le siège de Constantinople et le Patriarcat Ecuménique, III, Les églises et les monastères, 2nd ed., Institut français d'études byzantines, Paris, 1969.

Kašanin, Milan, "Bela crkva Karanska" ["Bela crkva from Karan"], in Starinar, ser. 3, t. 4 (1926-1927).

Konstantinidi, Chara, Ho Melismos: hoi sylleitourgountes hierarches kai hoi aggelloi-diakonoi mprosta stēn Hagia Trapeza me ta timia dōra ē ton eucharistiako Christo [Melismos: The Officiating Bishops and the Deacon Angels in front of the Altar with the Liturgical Offering or the Eucharistic Christ], Kentro Byzantinōn Ereunōn, Thessaloniki, 2008.

Kriza, Ágnes, "The Russian Gnadenstuhl", in Journal of the Warburg and Courtauld Institutes, t. 79 (2016).

Mihăilă, Gheorghe, "Tradiția literară constantiniană de la Eusebiu al Cezareei la Nichifor Calist Xanthopoulos, Eftimie al Tîrnovei și domnii țărilor române"["The Literary Tradition Concerning Constantine the Great from Eusebiu of Caesarea to Nichifor Calist Xanthopoulos, Eftimie of Tîrnova and the rulers of Romanian principalities"], in Cultură și literatură română veche în context european: studii și texte [Old Romanian Culture and Literature in European Context: studies and texts], Editura Științifică și Enciclopedică, Bucharest, 1979.

Millet, Gabriel; Frolow, Anatole, La peinture du moyen âge en Yougoslavie [The Painting of the Middle Ages in Yugoslavia], II, de Boccard, Paris, 1957.

Okunev, Nikolaj, "Les peintures murales à l'église de Sopoćani”, in Byzantinoslavica, t. 1 (1929).

Pillat, Cornelia, Pictura murală în Țara Românească în epoca lui Matei Basarab [The Wall Painting in Wallachia during the Reign of Matei Basarab], "Meridiane" Publishing House, Bucharest, 1980.

Popa, Corina; Iancovescu, Ioana; Bedros, Vlad; Negrău, Elisabeta, Repertoriul picturii murale brâncovenești: I. Județul Vâlcea [The Inventory of Brancovan Wall Painting], Publishing House of the National University of Arts, Bucharest, 2008.

Tasić, Dušan, "Les peintures de l'église médiévale de Prokuplje", in Zbornik za Likovne Umetnosti Matice Srpski, t. 3 (1967).

Todić, Branislav, "L'Apôtre André et les Archevêques Serbes sur les fresques de Sopoćani", in Byzantion, t. 72 (2002).

Todić, B., "Représentations de Papes Romains dans l'église Sainte-Sophie d'Ohrid. Contribution à l'idéologie de l'archevêché d'Ohrid", in Deltion tēs Christianikēs Archaiologikēs Hetaireias, ser. 4, t. 29 (2008), pp. 105-118.

Todić, B., Manastir Resava, Agencija “Draganić”, Belgrade, 1995.

Ulea, Sorin, "La peinture extérieure moldave: où, quand et comment est-elle apparue", in Revue Roumaine d'Histoire, t. 23 (1984), no. 4.

Văetiși, Atanasia, "Ansamblul pictural al bisericii Mănăstirii Snagov" ["The Murals from the Church of Snagov Monastery"], in Mănăstirea Snagov: istorie și artă [Snagov Monastery: History and Art], "Cuvântul vieții" Publishing House, Bucharest, 2011.

Walter, Christopher, Art and Ritual of the Byzantine Church, Variorum Publications, London, 1982. 